\author{
Alenka Bartulović \\ alenka.bartulovic@ff.uni-lj.si \\ Instytut Etnologii i Antropologii Kulturowej \\ Wydział Sztuki \\ Uniwersytet w Lublanie
}

\title{
Postjugosłowiańskie interpretacje orientalizmu Ivo Andricia: niejednoznaczność osmańskiego dziedzictwa w Bośni i Hercegowinie ${ }^{1}$
}

\author{
Post-Yugoslav Readings of Ivo Andric's Orientalism: The \\ Ambivalence of Ottoman Legacy in Bosnia-Herzegovina
}

\begin{abstract}
Streszczenie: W sprzecznych wyobrażeniach o przeszłości bośniacko-osmańskiej, w latach dziewięćdziesiątych XX wieku reinterpretowanej pragmatycznie przez pryzmat nacjonalizmu w krajach byłej Jugosławii, najsłynniejsze postacie w historii Bośni zazwyczaj przedstawiane są w bardzo różny sposób. W tym kontekście laureat Nagrody Nobla Ivo Andrić wyróżnia się jako jeden z najczęściej przywoływanych (i krytykowanych) pisarzy bośniackich. Rozpad republiki Jugosławii miał ogromny wpływ na ocenę Andricia i jego dzieł. Do twórczości Andricia rościli sobie prawa przede wszystkim Serbowie, a w mniejszym stopniu także i Chorwaci. Boszniacy natomiast starali się wręcz wymazać pisarza z kart historii, klasyfikując go jako zagorzałego zwolennika orientalizmu.

Artykuł przedstawia prezentowany przez Andricia wariant orientalizmu, umiejętnie wkomponowany w jego twórczość literacką, widoczny także w jedynym napisanym przez niego dziele naukowym - pracy doktorskiej zatytułowanej Rozwój życia duchowego Bośni w czasach panowania tureckiego. W artykule znajduje się krótka analiza dyskursywna tej pracy; szczególny nacisk położono na omówienie sposobu, w jaki Andrić prezentował wpływy osmańskie widoczne w życiu społecznym, kulturalnym i politycznym Bośni. Analiza wykazuje, że poglądy Andricia na osmańską spuściznę początkowo ewoluowały jako dialog z orientalizmem habsburskim i austro-węgierskim, a także z ideologią formującego się Królestwa Serbów, Chorwatów i Słoweńców (państwa jugosłowiańskiego). Napisane przez samego Andricia komentarze do pracy doktorskiej sugerują, że nie mamy tu do czynienia ze spójną i niezmienną perspektywą orientalistyczną, a raczej z wysoce wieloznacznym rozumieniem islamu i dziedzictwa osmańskiego. Artykuł ukazuje też, jak poglądy Andricia na osmańskie dziedzictwo są (błędnie) interpretowane w środowisku boszniackich intelektualistów oraz analizuje rolę Andricia w procesie tworzenia świadomości narodowej w powojennej Bośni i Hercegowinie.
\end{abstract}

Słowa kluczowe: Ivo Andrić, orientalizm, Bośnia i Hercegowina, dziedzictwo

Tłumaczenie: Klaudyna Michałowicz

\footnotetext{
${ }^{1}$ Tekst z języka angielskiego przetłumaczyła Klaudyna Michałowicz.
} 


\begin{abstract}
Summary: Conflicting understandings of the Ottoman and Bosnian past, which has been pragmatically reinterpreted through the nationalising gaze in the 1990s in the former Yugoslav space, tend to encompass different reinterpretations of the most prominent Bosnian (historical) figures. The Nobel Laureate Ivo Andrić stands out as one of the most politically (ab)used writers in Bosnian history. The dissolution of Yugoslavia deeply affected the reception of Andrić and his works. While both Serbs and, to a lesser extent, Croats claimed exclusive ownership of Andrić's qualities, many Bosniaks made attempts to write him out of history, claiming that Andrić was a strong proponent of orientalism. The article traces a unique Andrić's brand of orientalism, which is skilfully woven not only into Andrić's literary works, but is also prominent in his only scientific work, a doctoral dissertation entitled The Development of Spiritual Life in Bosnia Under the Influence of Turkish Rule. Hence, the article offers a short discursive analysis of Andrić's dissertation, with special focus on his depiction of Ottoman influence on Bosnian social, cultural, and political life. An analysis indicates the early stages of Andrić's thinking about the Ottoman legacy, developed in dialogue with the Habsburg or Austro-Hungarian orientalism and ideas of the new or still emerging Kingdom of Serbs, Croats, and Slovenians (Yugoslav state). Andrić's reactions to his own dissertation suggest that, we cannot speak of an unchanging and coherent orientalist perspective, but rather of a highly ambivalent understanding of Islam and the Ottoman legacy. Current (mis) understandings of Andrić's reading of Ottoman legacy among a circle of Bosniak intellectuals are also exposed, with the aim to explore the position of Andrić in the process of nation-building in post-war BH.
\end{abstract}

Key words: Ivo Andrić, orientalism, Bosnia-Herzegovina, legacy

Translated by Author

Jesienią 2005 roku w Mahovljani, wiosce niedaleko Banja Luki, natrafiłam na graffiti komentujące decyzję komisji międzynarodowej, która nakazała połączenie sił zbrojnych obu części składowych Bośni i Hercegowiny (Republiki Serbskiej oraz Federacji Bośni i Hercegowiny) w jedną armię narodową². Ktoś, kto wyraźnie sprzeciwiał się idei połączenia niezależnych części składowych Bośni i Hercegowiny w funkcjonalne, bardziej scentralizowane państwo, i postrzegał ten krok jako odrodzenie Imperium Osmańskiego w XXI wieku, wypisał na ścianie zrujnowanego budynku następujące hasło: Ne damo decu u janičare! (Nie pozwolimy, by nasze dzieci zostały janczarami!) $)^{3}$. Graffiti to nie jest odosobnionym przypadkiem nawiązania do „użytecznej przeszłości” Bośni (Wertsch 2002), a w szczególności do długotrwałej obecności Turków osmańskich na Bałkanach. Wiele budynków wzniesionych w czasach panowania osmańskiego w miastach Bośni zostało

${ }^{2}$ Układ w Dayton położył kres wojnie, utrwalając jednak podział kraju na dwie jednostki oraz jeden dystrykt autonomiczny - Brčko. Chociaż Bośnia i Hercegowina (BIH) uznawana jest za suwerenne państwo, jego dwie części składowe funkcjonują niemal zupełnie niezależnie od siebie, zaś większość partii w BIH dąży do jeszcze większej decentralizacji i podziału kraju według granic narodowych. Siły zbrojne BIH zostały oficjalnie zjednoczone w 2005 r., pod wpływem nacisku ze strony społeczności międzynarodowej. Nadal jednak składają się one z armii obu jednostek założycielskich.

${ }^{3}$ Janczarzy to nazwa elitarnych jednostek osmańskich utworzonych w XIV w. Wcielani byli do niej młodzi chłopcy, z których większość wywodziła się z chrześcijańskich rodzin chłopskich mieszkających na Półwyspie Bałkańskim. Siłą zmuszano ich do przejścia na islam. 
zniszczonych w czasie wojny przez jednostki bośniackich Serbów i Chorwatów (zob. Hajdarpašić 2008: 715). W latach dziewięćdziesiątych XX wieku w serbskich mediach wielokrotnie słyszało się bezkrytyczne porównania do osmańskiej przeszłości; bośniackich muzułmanów określano często jako okrutnych, fanatycznych, reakcyjnych „Turków”. Przedstawiani byli oni jako niechciane dziedzictwo „tureckiego jarzma”, zdrajcy, którzy obrócili się przeciw swym (prawosławnym) słowiańskim pobratymcom. Taki obraz bośniackich muzułmanów idealnie pasuje do opisanej przez Todorovą koncepcji ,spuścizny osmańskiej jako percepcji” ściśle związanej z dyskursami narodowymi oraz nacjonalistycznymi (Todorova 1996). W sprzecznych wyobrażeniach o przeszłości bośniacko-osmańskiej, reinterpretowanej pragmatycznie przez pryzmat dominującej ideologii nacjonalistycznej, najsłynniejsze postacie w historii Bośni zazwyczaj przedstawiane są w bardzo różny sposób. Podobnie ambiwalentna jest ocena sposobu, w jaki ludzie ci postrzegali siebie samych oraz wielokulturowe i wielowyznaniowe społeczeństwo Bośni.

Laureat Nagrody Nobla Ivo Andrić (1892-1975) wyróżnia się jako jeden z najczęściej przywoływanych (i krytykowanych) pisarzy bośniackich. Zainteresowanie postacią Andricia nie powinno nikogo dziwić, zważywszy, że był on jednym z najbardziej rozpoznawanych na arenie międzynarodowej literatów wywodzących się z byłej Jugosławii; odnosił sukcesy także jako dyplomata. Badacze w większości zgadzają się co do faktu, że Andrić często dostosowywał się do potrzeb zmieniającej się władzy. Jego niejednoznaczna autopercepcja powodowała, że niejednokrotnie podkreślał on różne aspekty swojej tożsamości (czasami, choć rzadko, wyłącznie narodowościowe), by uzasadnić własną postawę i stworzyć sobie okazję do odnoszenia dalszych sukcesów.

Andrić przyszedł na świat w rodzinie katolickiej w Trawniku, na krótko po tym, jak terytorium Bośni i Hercegowiny dostało się pod rządy Austro-Węgier. Początkowo uważany był za Chorwata i jak się wydaje do lat dwudziestych XX wieku nie protestował przeciwko takiej kategoryzacji. Od tego czasu coraz częściej, choć nie wyłącznie (zob. Lovrenović 2008: 33) decydował się pisać w dialekcie ekawskim, sugerując tym samym swoją przynależność do narodu serbskiego. Można jednak dowodzić, że Andrić niejednokrotnie utożsamiał nacjonalizm serbski z jugoslawizmem, zaś serbsko-chorwacki uważał za jeden język (Sang Hun 2011: 52). W latach sześćdziesiątych mocno podkreślał swoje zaangażowanie w ideę utworzenia państwa jugosłowiańskiego. Z dumą przypominał, że należał do organizacji Mlada Bosna (Młoda Bośnia) (Wachtel 1998: 274) oraz że został wychowany „w duchu jugosłowiańskim” (Rizvić 1995: 665). Chociaż jeszcze w roku 1914 utwory Andricia znajdowały się w Antologii młodej chorwackiej poezji lirycznej, pisarz stopniowo odsuwał się od stosowania kategoryzacji czysto narodowościowych. 
W 1933 roku nie przyjął zaproszenia do Antologii gawędziarzy chorwackich, tak uzasadniając swoją decyzję:

\begin{abstract}
Nie mogę się zgodzić, by moje utwory figurowały w zbiorze, z którego wyklucza się bliskich mi poetów tylko dlatego, że są oni innego wyznania lub też urodzili się w innej prowincji. Przekonań tych nie nabyłem niedawno - żywiłem je od wczesnej młodości, a jako człowiek dojrzały wyznaję te same podstawowe zasady (Sang Hun 2011: 52, 54).
\end{abstract}

W rozmowie z Ljubą Jandrić, przeprowadzonej w 1971 roku, literat kładł nacisk jedynie na spójne aspekty własnej tożsamości, podkreślając lojalność wobec idei Jugosławii (zob. Lovrenović 2008: 15; Sang Hun 2011: 54). Chociaż dokładał wszelkich starań, by wyjaśnić swoje poglądy w kwestiach kultury i polityki, jego wypowiedzi bywały po prostu ignorowane. Co więcej, kontrowersje dotyczące tożsamości Andricia były przedmiotem dyskusji jeszcze długo po śmierci pisarza i rozpadzie Jugosławii.

W latach krwawej dezintegracji Jugosławii wiele grup próbowało przedstawiać Andricia jako rodaka, roszcząc sobie prawa do jego twórczości oraz do sławy, jaką przyniosła mu literacka Nagroda Nobla, którą otrzymał w 1961 roku za powieść Most na Drinie. Dysputy prowadzono nie tylko na gruncie kulturowym, ale też politycznym, ponieważ dzieła pisarza wielokrotnie wykorzystywane były jako podstawa historyczna (sic!) do wyjaśniania zbrodni wojennych oraz rzekomo niekończących się sporów na tle etnicznym w Bośni i Hercegowinie. Tym samym rozpad Jugosławii miał ogromny wpływ na odbiór Andricia i jego twórczości (zob. Kazaz 2000; Lovrenović 2008; Sang Hun 2011).

Prezentowanych przez każdą z trzech głównych grup narodowościowych w Bośni i Hercegowinie (Serbów, Chorwatów i Boszniaków, czyli bośniackich muzułmanów) postaw wobec Andricia nie da się sprowadzić do jednego „narodowego” wyobrażenia, należy jednak zauważyć, że w latach dziewięćdziesiątych postać pisarza była instrumentalizowana przez elity polityczne i kulturalne, które strategicznie korzystały z jego wizerunku, by umocnić segregację narodową wśród byłych sąsiadów z Jugosławii. Serbowie, a w mniejszym stopniu także i Chorwaci ${ }^{4}$, rościli sobie wyłączne prawo do twórczości i sławy Andricia, stawiając jego pomniki ${ }^{5}$, podczas gdy Boszniacy aktywnie starali się wymazać go z kart historii i wyeliminować z edukacji młodzieży (zob. Huković 2000)

${ }^{4}$ W środowisku (bośniackich) Chorwatów postać Andricia postrzegana jest w sposób sprzeczny i niejednoznaczny. Np. w latach dziewięćdziesiątych teksty Andricia usunięto z podręczników w Chorwacji (Longinović 1995: 137). Decyzję tę tłumaczono stwierdzeniem, że sam pisarz rzekomo nie przyznawał się do chorwackiego pochodzenia. Bardziej szczegółowa analiza oceny Andricia we współczesnej Chorwacji i w środowisku Chorwatów bośniackich zob. Lovrenović 2008; Sang Hun 2011.

${ }^{5}$ W 1992 r. pomnik Ivo Andricia stanął w Belgradzie. Dziesięć lat później kolejny monument pojawił się w rodzinnej miejscowości pisarza, Trawniku. Miejscowy kapłan Pavo Nikolić (przy wsparciu kardynała Bośni i Hercegowiny, Vinko Puljicia) upamiętnił w ten sposób sto dziesiątą rocznicę urodzin Andricia (Ša$\operatorname{rac} 2002)$. 
oraz z przestrzeni publicznych. O różnicach w rozumieniu roli Andricia najdobitniej świadczy incydent, jaki miał miejsce na początku lipca 1991 roku w Wiszegradzie ${ }^{6}$. Sprawca nazwiskiem Murat Šabanović wyrzucił popiersie Andricia do rzeki Driny. Dużo później stwierdził w wywiadzie dla czasopisma „Slobodna Bosna”, że do pozbycia się „Rushdiego Bośni” zachęcali go muzułmańscy przywódcy polityczni (Sang Hun 2011: 55-56). Zdarzenie to wykorzystał Slobodan Milošević podczas swojego procesu w Hadze, przedstawiając zniszczenie pomnika Andricia jako ewidentny dowód „antagonistycznej tolerancji” w Bośni i Hercegowinie, a w szczególności dyskryminacji Serbów, która jego zdaniem była bezpośrednim powodem wojny (zob. Humanitarian Low Center).

Sprzeciw Boszniaków wobec gloryfikacji Andricia wynika z przekonania, że pisarz propagował orientalizm i żywił poglądy antymuzułmańskie. W bardziej radykalnych interpretacjach Andrić uważany jest też za ideologicznego architekta koncepcji Wielkiej Serbii. Enver Kazaz, jeden z niewielu intelektualistów odżegnujących się od nacjonalistycznej recepcji dzieł Andricia, kategorycznie sprzeciwia się ekstremalnej interpretacji boszniackich nacjonalistów. Nawet on przyznaje jednak, że w twórczości tego pisarza obecne są nuty orientalizmu. Nurt ten przyjmuje u Andricia bardzo charakterystyczną formę, przesiąkniętą niejednoznacznym stosunkiem wobec muzułmanów i islamu. Zauważyć to można także w jego jedynej pracy naukowej - rozprawie doktorskiej zatytułowanej Rozwój życia duchowego Bośni w czasach panowania tureckiego (Die Entwicklung des geistigen Lebens in Bosnien unter der Einwirkung der türkischen Herrschaft), którą obronił w Grazu w 1924 roku. Chociaż doktoratowi Andricia poświęcono kilka opracowań, w analizie naukowej jest on raczej pomijany; jego autor był przecież literatem mocno inspirującym się burzliwą historią kraju, który przez stulecia idealnie pasował do kategorii ,peryferium Europy”.

Prezentowany artykuł jest dyskursywną analizą pracy doktorskiej Ivo Andricia, koncentruje się na kreowanym przez literata obrazie wpływów osmańskich na życie społeczne, kulturowe i polityczne Bośni. Tekst dowodzi, że poglądy Andricia na osmańską spuściznę początkowo ewoluowały jako dialog z orientalizmem habsburskim i austro-węgierskim, a także z ideologią formującego się Królestwa Serbów, Chorwatów i Słoweńców, a później państwa jugosłowiańskiego. Napisane przez samego Andricia komentarze do jego pracy doktorskiej, a także wprowadzone później poprawki sugerują, że nie mamy tu do czynienia ze spójną i niezmienną perspektywą orientalistyczną, a raczej z wysoce wieloznacznym rozumieniem islamu, dziedzictwa osmańskiego oraz skomplikowanego problemu tożsamości na Bałkanach (a w szczególności w Bośni i Hercegowinie).

\footnotetext{
${ }^{6} \mathrm{~W}$ Wiszegradzie znajduje się również ideologicznie nacechowany kompleks turystyczny o nazwie Andrićgrad, stworzony przez słynnego reżysera Emira Nemanję Kusturicę.
} 
Półwysep Bałkański niejednokrotnie określany był jako przestrzeń graniczna (Todorova 1999: 37), obszar pośredni (zob. Bhabha 1996), węzeł, w którym przecina się wiele kulturowych dróg. W artykule zostaną także przedstawione współczesne interpretacje orientalizmu Andricia i osmańskiego dziedzictwa prezentowane przez boszniackich intelektualistów, ukazujące rolę, jaką ów literat odegrał w procesie kształtowania świadomości narodowej w powojennej Bośni i Hercegowinie.

\section{Orientalizm Andricia - wprowadzenie}

W napisanym do pewnego młodego nauczyciela liście, Andrić wyjaśniał tło historyczne swojej powieści Травничкахроника (przekład polski: Konsulowie ich cesarskich mości) stwierdzając, że od zawsze fascynowały go „kontakty Wschodu z Zachodem, zarówno w sensie współpracy, jak i w sensie zderzenia kultur" (Karaulac 2003: 319). W jego dziełach, nawet tych napisanych w szkole średniej, wyraźnie widać zainteresowanie kulturą muzułmańską i islamem7 . Choć przylgnęła do niego łatka orientalisty, Andrić prezentował islam i muzułmanów w sposób bardzo różnorodny, a czasami wręcz sprzeczny, jaki nie daje się sprowadzić do jednego spójnego obrazu.

Niemal trzydzieści lat po publikacji rewolucyjnej książki Edwarda Saida zatytułowanej Orientalizm (1996), w środowisku akademickim wykrystalizował się nowy podgatunek orientalizmu, który krytycznie odnosi się do ujednoliconej percepcji wyimaginowanego „obcego" - Orientu i Okcydentu postrzeganych jako dwie homogeniczne jednostki. Stąd właśnie wywodzą się obecnie istniejące spojrzenia na orientalizm, takie jak orientalizm graniczny (frontier orientalism; Gingrich 1996), praktyczny (practical orientalism; Herzfeld 1997: 96), codzienny (everyday orientalism; Jansen 2002) i reprodukowany (nesting orientalism; Bakić-Hayden 1995), a także różne odmiany orientalizmów narodowych (zob. Kotje 2004), nawet imperialnych (zob. Makdisi 2002). Obserwując dyskurs orientalistyczny w specyficznym kontekście i analizując go na szerszym tle historycznym można zauważyć, że natura owego trendu się zmienia (zob. Gingrich 1996). Nadal jednak wyraźnie rysuje się tendencja do narzucania jednostkom kolektywnych obrazów Orientu i jego mieszkańców, ignorowania zmian oraz nieścisłości w ich poglądach i przekonaniach.

W latach dziewięćdziesiątych XX wieku, w stosunkowo wpływowych kręgach boszniackich intelektualistów, oskarżanie Andricia o orientalizm stało się wręcz ważnym aspektem krytyki literackiej. Analiza tych zarzutów znajduje się w dalszej części artykułu; w tym miejscu należy jedynie wspomnieć, że najgłośniejszym krytykiem Andricia był

\footnotetext{
${ }^{7}$ Koledzy ze szkoły średniej wspominali, że pewnego razu nauczyciel poprosił Andricia, aby przeczytał głośno swoje wypracowanie i pochwalił napisaną przez niego opowieść o muzułmańskiej dziewczynie grającej na akordeonie i śpiewającej sevdalinkę (Karaulac 2003: 51).
} 
historyk literatury Muhsin Rizvić. W szczegółowym opracowaniu „antyislamskich” utworów Andricia, Rizvić stwierdza, że pisarz ten zataczał „obsesyjne kręgi (...) pomiędzy turecką trucizną a odurzającym nektarem egzotycznego świata" (Rizvić 1995: 626). Zaangażowanie, z jakim Andrić bronił Baščaršiji (starego centrum miasta) w Sarajewie, a także wielu meczetów i budynków wzniesionych za czasów panowania osmańskiego (Rizvić 1995: 616) ${ }^{8}$, stawia poglądy Rizvicia pod znakiem zapytania. Z drugiej strony trzeba pamiętać jednak o poglądach, jakie wyrażał Andrić w swojej rozprawie doktorskiej, w której wpływy osmańskie uznawał za „absolutnie negatywne” (Andrić 1994: 50).

Orientalizm Andricia każe nam zwrócić uwagę na kontekst historyczny i spojrzeć na niego przez pryzmat sytuacji politycznej i kulturowej. W czasach istnienia Królestwa Serbów, Chorwatów i Słoweńców (późniejszej Jugosławii), Andrić reprezentował interesy frakcji proserbskiej, powiązanej z koncepcją Jugosłowian. Potwierdzeniem tego jest również fakt, że w okresie międzywojennym Andrić zrobił karierę jako dyplomata (Wachtel 1998: 156$)^{9}$; to osiągnięcia na tym polu zmotywowały go do napisania pracy doktorskiej. W 1923 roku weszło bowiem w życie rozporządzenie, w myśl którego od osób zajmujących stanowiska polityczne zaczęto wymagać odpowiednich kwalifikacji. Andrić nie ukończył studiów, lecz chcąc kontynuować karierę dyplomatyczną, musiał bezzwłocznie uzyskać stopień doktorski (Rizvić 1995: 33). Postawa jaką prezentował w swojej pracy była uwarunkowana także innymi czynnikami: nie można zapominać, że kształcił się w Austro-Węgrzech oraz że pochodził z katolickiej rodziny, w której pamiętano jeszcze, jak to jest należeć do społeczności okrytej hańbą. Odziedziczył wspomnienia rajów, którzy w Imperium Osmańskim stanowili obywateli drugiej kategorii. Nie ma wątpliwości, że pisarz mocno się z tą grupą identyfikował.

W roku 1914 Ivo Andrić został aresztowany przez władze austro-węgierskie za pro-jugosłowiański aktywizm. Następne trzy lata spędził w więzieniu (Sang Hun 2011: 53). Choć protestował przeciwko prowadzonej na terytorium Bośni polityce imperialistycznej, był gotów przyjąć pewne aspekty owego szczególnego typu imperialnego orientalizmu. Warto zauważyć, że wcielając Bośnię i Hercegowinę do Austro-Węgier, nowe władze uczyniły zeń „bliską kolonię” (zob. Donia 2013). Jak pisze Stijin Vervaet, na

\footnotetext{
${ }^{8}$ Pod koniec lat czterdziestych XX w. pojawiły się plany stopniowej rozbiórki dzielnicy Baščaršija. Ocaliły ją starania kilku znanych architektów, którzy w latach pięćdziesiątych i sześćdziesiątych z powodzeniem godzili osmańskie dziedzictwo ze standardami, jakich wymagano w socjalistycznej Jugosławii. Starówkę udało się nawet wypromować jako atrakcję turystyczną. W tym samym okresie partia komunistyczna zrewidowała swoją postawę wobec „narodów i narodowości”, zwracając szczególną uwagę na muzułmańską część społeczeństwa (Hajdarpašić 2008: 728).

${ }_{9}^{9}$ Andrić był zawodowym dyplomatą. W Ministerstwie Spraw Zagranicznych Królestwa Jugosławii pełnił wysokie urzędy. W okresie międzywojennym pracował także jako ambasador jugosłowiański w Berlinie (zob. Sang Hun 2011: 53).
} 
wpół kolonialna retoryka narzucona przez to mocarstwo byłym prowincjom osmańskim, nie różniła się wielce od dyskursu izolacjonistycznego stosowanego przez zwolenników stworzenia państwa zachodnio-bałkańskiego (Vervaet 2009: 1). Imperialistyczne koncepcje Austriaków oraz negatywny obraz osmańskiego dziedzictwa kreowany na terenie Jugosławii (zob. Hajderpašić 2008; Lovrenović 2008), znacząco wpłynęły na prezentowane przez Andricia poglądy na muzułmanów i pokonane Imperium Osmańskie ${ }^{10}$. Zaważyły też na wyborze źródeł, do których autor odnosił się w swojej pracy doktorskiej. Choć zapewnia w niej, że przedstawiony przezeń zarys historii Bośni i Hercegowiny opiera się zarówno na źródłach chrześcijańskich, jak i muzułmańskich (Andrić 1994: 47), tych drugich jest $\mathrm{w}$ istocie bardzo niewiele. W charakterystyczny dla orientalistów sposób Andrić nie dopuszcza muzułmańskich autorów do głosu. Na przykład prace Safvet-beg Bašagicia dotyczące muzułmańskiej poezji nazywa silnie tendencyjnymi i napisanymi „w duchu muzułmańskim” (Andrić 1994: 47). Zdaniem Andricia takich źródeł nie można uważać za wiarygodne ani cytować ich w pracach naukowych. W tym przypadku brak poszanowania dla odmiennych punktów widzenia wynika po części $\mathrm{z}$ bariery językowej. Andrić nie znał tureckiego - zauważył to już jeden z recenzentów jego pracy, Heinrich Felix Schmid (Rizvić 1995: 52). Reasumując, Andrić opierał się głównie na kronikach, annałach i listach napisanych w klasztorach franciszkańskich i prawosławnych, a przedstawiony w nich obraz Imperium Osmańskiego uznawał za wierny i prawdziwy. Cytował więc te źródła bezkrytycznie. Wydaje się też, że z ufnością przyjmował relacje zagranicznych autorów, którzy pozostawili po sobie zapiski z podróży po Bośni i Hercegowinie, ignorując fakt, iż wiele z tych dzieł nie tylko stanowiło odzwierciedlenie poglądów bałkanistycznych (zob. m.in. Jezernik 2004), lecz także funkcjonowało jako materiał mający podsycać nastroje antyosmańskie ${ }^{11}$, istotne w procesie rozwoju zjawiska nazwanego przez Andre Gingricha „orientalizmem granicznym” (Gingrich 1996) ${ }^{12}$. Widoczną w pracy Andricia naiwną wiarę w orientalistyczny dyskurs zachodni, interpretować można jako bezpośrednią konsekwencję rozłamu pomiędzy chrześcijaństwem a islamem, który pchnął chrześcijańskie społeczności na Bałkanach w strefę wpływów Rosji oraz Europy Zachodniej (Todorova 1996: 58). Andrić, który

\footnotetext{
${ }^{10}$ Edin Hajdarpašić (2008) analizuje nieliczne źródła opisujące spuściznę osmańską na Bałkanach z innej perspektywy.

${ }^{11}$ Strach przed osmańskimi Turkami bywał wywoływany i podsycany jak najbardziej celowo. Władze już od XVI w. stosowały rozmaite mechanizmy „propagandy antytureckiej” głównie dlatego, że strach i brak stabilizacji służył ich celom politycznym bądź ekonomicznym (Todorova 1999: 120-121).

${ }^{12}$ Jest to stosunkowo spójny zestaw mitów i metafor obecnych w kulturze ludowej i popularnej Europy Południowo-Wschodniej i Środkowej - czyli obszaru, który na przestrzeni dziejów miewał kontakty z peryferiami Imperium Osmańskiego. Zazwyczaj chodzi o mit przedmurza chrześcijaństwa i koncepcję prześladowań (Gingrich 1996; zob. też: Bartulović 2010; Baskar 2010).
} 
buntował się przeciwko władzom austro-węgierskim - chociaż doceniał ich kosmopolityzm i dążenie ku modernizacji i podnoszenia poziomu wykształcenia obywateli (zob. Lovrenović 2008: 7) - czuł się najbardziej komfortowo w kręgach intelektualistów zachodnich (Loud 1995: 190).

\section{Obraz Imperium Osmańskiego przedstawiony przez Andricia w 1924 roku}

Dysertacja Andricia przedstawia szablonową historię nagłej inwazji cywilizacji wyraźnie obcej i niemal barbarzyńskiej, motywowanej do działania nakazami swej fanatycznej, agresywnej wiary. Zdaniem Andricia „najazd Turków” wywołał „katastrofę”, zahamował rzekomo naturalny rozwój protonacji i doszczętnie zniszczył wszystkie zdobycze cywilizacyjne uzyskane przez niezawisłe kraje bałkańskie w średniowieczu. Podsumowaniem owego punktu widzenia jest następujący fragment pracy:

Rzecz w tym, że w krytycznym momencie rozwoju, kiedy jej duchowa siła dojrzewała, by wydać owoc, Bośnia została podbita przez wojowniczy lud azjatycki, którego zwyczaje i instytucje społeczne stanowiły antytezę wszelkich form kultury chrześcijańskiej, a którego religia - narodzona w innych warunkach klimatycznych i społecznych, a niezdolna do adaptacji - zaburzyła duchowe życie tej krainy, wykrzywiła je, tworząc coś zupełnie wyjątkowego (Andrić 1994: 25).

By udowodnić zasadność powyższego twierdzenia, Andrić zaczyna swoją opowieść od opisu Bośni i Hercegowiny sprzed czasów osmańskich - regionu o „całkowicie oryginalnej kulturze narodowej" ${ }^{14}$. Jego zdaniem kultura ta wyewoluowała jako amalgamat lokalnego „ducha narodowego" (Andrić 1994: 9) i wpływów z zewnątrz, które mogły się rozwinąć w środowisku Bośni i Hercegowiny. Sieć powiązań kulturowych łączyła wówczas ten region z Cesarstwem Rzymskim i Bizancjum. Do Bośni i Hercegowiny dotarły też zdobycze kulturowe położonego niedaleko Dubrownika, choć Andrić argumentuje, że dominująca pozycja bogomilców ${ }^{15}$ o „wschodnim pochodzeniu” (Andrić 1994: 10) niosła ze sobą opór przeciwko wszystkiemu, co dałoby się określić jako „postępowe”, „cywilizowane” i „zachodnie”. Mimo widocznej tu i ówdzie idealizacji, Andrić nie pisze

\footnotetext{
${ }^{13}$ Należy zaznaczyć, że niemal w całej pracy Andrić stosuje termin „Turek” w odniesieniu zarówno do ludności osmańskiej, jak i muzułmanów zamieszkałych w Bośni i Hercegowinie.

${ }^{14}$ Andrić powtarza tu tezę postawioną przez Johanna de Asboth.

${ }^{15}$ Heretycka sekta bogomilców, która powstała w Bułgarii w X w., w XI i XII w. zyskała na Bałkanach wielu zwolenników. Czołowym głosicielem teorii o związkach pomiędzy bogomilcami a kościołem bośniackim był chorwacki historyk Franjo Rački. W XX w. jego poglądy zyskały popularność wśród boszniackich intelektualistów. W przededniu wojny w Bośni i Hercegowinie pomysł, że miejscowi muzułmanie mogliby przedstawiać siebie jako spadkobierców autentycznego kościoła bośniackiego, wydał się bardzo użyteczny. Teoria ta została jednak mocno skrytykowana przez wielu późniejszych badaczy (zob. Malcolm 1994: 27-29).
} 
o przedosmańskiej Bośni z patetycznym uwielbieniem, ani też nie wyraża entuzjazmu wobec wszystkiego, co „pochodzi z zachodu”. Krytycznie wypowiada się o cudzoziemskich apetytach terytorialnych w Bośni, które jego zdaniem były główną przyczyną supremacji bogomilców. W jego wizji to zakusy państw ościennych sprawiły, że Bośnia i Hercegowina znalazła się pod ,jarzmem Wschodu” (Andrić 1994: 19). Przywiązanie Andricia do idei niepodległego państwa Słowian Południowych jest tu widoczne szczególnie wyraźnie, chociaż miejscami wciąż przejawia on przekonania polityczne wynikające z kolonialnego podejścia monarchii austro-węgierskiej.

Andrić próbuje na przykład udowodnić, że bogomilcy i muzułmanie są sobie kulturowo bliscy. Koncepcja ta powtarzana była przez wielu uczonych z Austro-Węgier, skłonnych dostosować się do politycznych potrzeb władz, które desperacko starały się przekształcić Bośniaków w zjednoczony naród, by osłabić wpływ nacjonalistów z krajów z Bośnią sąsiadujących. Pragnąc stworzyć ogólnobośniacką kulturę, Benjámin Kállay pokładał całą nadzieję w społeczności muzułmańskiej, ponieważ tej grupy nie można było powiązać z żadnymi zwolennikami spoza granic kraju (Malcolm 2002: 148). Do narzędzi mających podnieść status Boszniaków należały systematyczne próby wykazania ciągłości pomiędzy bogomilcami a bośniackimi muzułmanami (Kamberović 2003: 77; Aleksov 2003: 236). Nazywając bośniackich muzułmanów „potomkami bogomilców” (1994: 45), Andrić wpisuje się więc w austro-węgierskie tendencje. Zauważa podobieństwa w architekturze sakralnej i przejawianą przez obie grupy niechęć do kościelnych dzwonów, krzyża i wody święconej (Andrić 1994: 18, 41-42). Ulega też rozpowszechnionej na początku XX w. modzie na analizy charakterologiczne, wymieniając dwie negatywne cechy rzekomo wspólne dla bogomilców i bośniackich muzułmanów: oportunizm i „niezdrowy konserwatyzm” (Andrić 1994: 45). Odrzuca teorię o pokojowej, dobrowolnej islamizacji, ponieważ kłóci się ona z koncepcją Turków jako narodu agresywnego i „wojowniczego" (Andrić 1994: 12). Akceptując tę teorię musiałby przyznać, że Imperium Osmańskie prowadziło stosunkowo tolerancyjną politykę wobec swoich poddanych ${ }^{16}$. Nie podaje jednak żadnych przykładów przymusowej islamizacji; próbuje bronić swojej tezy, skupiając się na głębokim przywiązaniu do rodzinnej ziemi odczuwanym przez arystokrację Bośni i Hercegowiny.

Zdaniem Andricia władze osmańskie postawiły ludność bośniacką przed wyborem: mogli zachować swoje prawa, przywileje i posiadłości albo też należeć do „marginalizowanej społeczność (raya) pozbawionej praw i ziemi" (Andrić 1994: 27). Autor przyrównuje ów dylemat do „przymusowej zmiany wyznania” (Andrić 1994: 27) właśnie

\footnotetext{
${ }^{16}$ Nazywanie osmańskiej Bośni społeczeństwem idealnie tolerancyjnym byłoby, oczywiście, mylące. Imperium Osmańskie było państwem teokratycznym, opartym na ścisłej hierarchii religijnej, w której uprzywilejowaną pozycję zajmowali muzułmanie (Džaja 2003: 52; Lovrenović 2002: 308; Todorova 1996: 47).
} 
W związku z przywiązaniem do ziemi wykazywanym przez ówczesnych arystokratów. Opis islamizacji opiera na dziełach badaczy, których autorytet cenił - Petara Petrovicia Njegoša i bośniackiego franciszkanina Ivana Franjo Jukicia. Cytuje dwa wersy z utworu Njegoša Gorski vijenac (Górski wieniec), w którym muzułmanie opisani są jako ludzie zdradzieccy, chciwi i tchórzliwi, którzy przeszli na islam z egoistycznych pobudek. Okrutny zwyczaj devşirme (poboru dzieci), do którego Andrić często odnosił się w swoich dziełach literackich, przedstawiony został także w jego pracy doktorskiej. Pisarz przytacza słowa Bartolomeja Geogijevicia, który opisuje dramat rodziców zmuszonych na zawsze rozstać się z dziećmi, dodając:

\footnotetext{
Jak zauważyliśmy wcześniej, uprowadzone dzieci niebawem zapominały o rodzinnym ognisku i wierze, przeistaczając się w fanatycznych „Turków”. Obdarzeni wrodzoną inteligencją i talentem potomkowie mężnych, krzepkich górali zyskiwali sławę i szacunek znacznie łatwiej niż leniwi, posiadający liczne wady Turcy (Andrić 1994: 30-31).
}

Andrić bardzo starał się udowodnić, że islamizacja wypchnęła Bośnię i Hercegowinę poza margines Europy powodując jej izolację. W jego ujęciu cały kraj odcięty został od cywilizacyjnego i kulturalnego postępu, jaki dokonywał się w tym czasie w Europie, nie tylko z powodu najazdu ,agresora o odmiennej wierze, naturze i rasie” (Andrić 1994: 26) oraz faktu, że miejscowa ludność była zadowolona z tego stanu rzeczy, lecz także dlatego, że samo Imperium Osmańskie stanowiło przeszkodę na drodze do jedności Słowian Południowych. Bośnia i Hercegowina stała się murem, który ,podzielił serbsko-chorwacką grupę etniczną i językową na dwoje” (Andrić 1994: 26). Andrić wyznaczał dla swej ,duchowej ojczyzny” inne zadanie:

\footnotetext{
Zgodnie ze swym położeniem geograficznym Bośnia powinna funkcjonować raczej jako most łączący ziemie dorzecza Dunaju z Morzem Adriatyckim, dwa peryferia dziedziny serbsko-chorwackiej, a zarazem dwa bardzo różne regiony kultury europejskiej. Przeszedłszy na islam, Bośnia nie była już w stanie pełnić jej naturalnej roli uczestnika w rozwoju kulturalnym chrześcijańskiej Europy (do której należała etnicznie i geograficznie). Za sprawą miejscowego elementu islamskiego stała się dla chrześcijańskiego Zachodu zawadą (Andrić 1994: 26).
}

Wydaje się, że na tym etapie autor był również zdania, że pełna integracja muzułmanów z przyszłymi strukturami narodowego państwa bałkańskiego nie jest możliwa (Carmichael 2002: 21). Przedstawiał ich zatem jako orientalnych obcych. Literackie i kulturowe dokonania franciszkanów i społeczności prawosławnych opisywał bardzo szczegółowo, chociaż nie zaliczał ich do estetycznie przyjemnych elementów ,zachodniej kultury wysokiej”. Dorobek kulturowy bośniackich muzułmanów zignorował niemal całkowicie. W swej pracy doktorskiej Andrić pisze, że muzułmanie, w przeciwieństwie do chrześcijan, nie czują potrzeby, by angażować się w zajęcia artystyczne 
ani intelektualne. Jako „dominująca kasta wojowników” koncentrują się na podbojach, a następnie na ochronie swej własności (Andrić 1994: 85). Był świadom istnienia literatury alhamijado ${ }^{17}$, lecz uważał ją za „należącą do zupełnie innej kultury” (Andrić 1994: 85) i - poniekąd przecząc sam sobie - przedstawiał alhamijado jako „twórczość hybrydową", która brutalnie zdeformowała język serbsko-chorwacki, wpychając go w ramy obcej formy poetyckiej (Andrić 1994: 86).

Maria Todorova argumentuje, że wzajemne wpływy etniczne i kulturowe, obecne na Bałkanach, oburzały i dziwiły europejskich obserwatorów bardziej niż orientalna obcość (Todorova 1999: 218). Wiele wskazuje na to, że Andrić także wierzył w konieczność stawiania wyraźnych granic pomiędzy Wschodem a Zachodem, kładąc wyraźny nacisk na napięcia pomiędzy muzułmanami a chrześcijanami. Rzadko identyfikował więc przypadki wzajemnych wpływów i hybrydyzacji, które - przynajmniej w pracy doktorskiej - przedstawiał jako proces niepożądany. Niekonsekwencja poglądów jest tu tym bardziej rażąca, że życie na bośniackich „rozdrożach” okazało się dla Andricia największym źródłem literackiej inspiracji. Mimo to w jednym z późniejszych komentarzy pisze, że jego doktoratu nie należy odbierać jako „krytyki kultury islamu”, a jedynie „analizę krytyczną skutków zaszczepienia tej religii w słowiańskim, chrześcijańskim kraju” (Andrić 1994: 92). Kiedy kładzie się nacisk na synkretyzm kulturowy i podobieństwa łączące społeczności, coraz trudniej jest stawiać wyraźne granice (Kolstø 2003: 26). Ponieważ europejskość wielokrotnie manifestowana była przez odcinanie się od rzekomo zupełnie obcych „Turków” (Mastnak 1998; Jezernik 2010), Andrić zwracał uwagę na kontrasty i prezentował bałkańskich chrześcijan jako lud należący do cywilizacji europejskiej. „Europa” była przecież synonimem postępu, porządku i dostatku; w wielu krajach bałkańskich jawiła się jako niedościgniony wzór (Todorova 1999: 81). Wyraźne próby zapewnienia sobie bezpiecznej i trwałej pozycji na arenie europejskiej wielokrotnie zawierały więc element wykluczania muzułmanów (Bartulović 2010; Lindstrom 2003). Bałkańscy nacjonaliści postrzegali zatem Imperium Osmańskie i islam jako coś obcego, decydując się na polityczny program deosmanizacji, który (przynajmniej częściowo) zaakceptował również Andrić.

\section{Rozliczanie się z Andriciem: uwagi o boszniackim statusie narodowym i spuściźnie osmańskiej}

Już w 1961 roku Šukrija Kurtović nazywał dzieła Andricia zagrożeniem dla jugosłowiańskiego „braterstwa i jedności” (Kurtović 2000). Jego krytykę opublikowano jednak

\footnotetext{
${ }^{17}$ Poezja alhamijado komponowana była w językach ojczystych używanych w Imperium Osmańskim, lecz zazwyczaj zapisywano ją pismem arabskim.
} 
tylko w czasopiśmie boszniackiej diaspory, ponieważ rząd jugosłowiański zabronił rozpowszechniania wszelkich materiałów podważających autorytet najsłynniejszego literata kraju (Lovrenović 2008: 20). W ślady Kurtovicia poszli dwaj boszniaccy intelektualiści, Muhamed Filipović (pod koniec lat sześćdziesiątych) oraz Muhsin Rizvić (w latach osiemdziesiątych, chociaż najważniejsza z jego publikacji dotyczących twórczości Andricia wydana została pośmiertnie w roku 1995). Tendencja ta utrzymała się także po wojnie w Bośni (1992-1995), kiedy to ze strony boszniackich elit intelektualnych pojawiły się głosy żądające usunięcia dzieł pisarza z podręczników, a jego wizerunków z przestrzeni publicznych. Muhidin Pašić, przewodniczący kulturalnego stowarzyszenia Preporod z siedzibą w Tuzli, w roku 1999 wystąpił z inicjatywą, by zmienić nazwy wszystkich ulic imienia Andricia. Wyjaśniał też powody boszniackiej niechęci wobec tego pisarza. Jego zdaniem Andrić „wyrażał patologiczną nienawiść do muzułmanów i islamu". Dzieła Andricia przedstawiał jako nawołujące do rozlewu krwi dodając, że autora tego w dużej mierze należy winić za akty ludobójstwa popełnione na Boszniakach w latach dziewięćdziesiątych - bardziej nawet niż elity polityczne dążące do utworzenia Wielkiej Serbii. Uważał go za ,jednego z ideologicznych architektów tego projektu”, przyrównując do zbrodniarzy wojennych i podsumowując: „Gdyby żył, prawdopodobnie dziś toczyłby się proces mający ustalić, na ile odpowiedzialny był za zbrodnie w Bośni, za wszelkie akty bezprawia, których ofiarą padła bośniacka ludność" (Stojić 1999).

Jest to oczywiście przekonanie o tyle radykalne, co nieobiektywne ${ }^{18}$. Wyrażany przez Envera Kazaza pogląd, że Andrić ,jest opium i koronnym argumentem ideologii prawicowych we wszelkich dyskusjach" (zob. Kazaz 2000), nawet pośród Boszniaków znajduje potwierdzenie w tym, że prezentowane w pracach boszniackich intelektualistów interpretacje dzieł Andricia, zebrane w pracy Andrić i Bošnjaci (Andrić i Boszniacy) (Maglajlić 2000), są stosunkowo jednolite i utrzymane w duchu nacjonalizmu. Przeprowadzona przez Kazaza analiza tej publikacji próbuje (od)tworzyć „odbiór dzieł Andricia na gruncie boszniackim". Prezentując wąski wybór cytatów z prac pisarza, w kontekście traumatycznych przeżyć i wciąż bolesnych oraz świeżych wspomnień z czasów wojny w Bośni, autorzy starają się narzucić pewien wspólny schemat rozumienia jego twórczości, aby umocnić poczucie bliskości i potrzeby wzajemnej pomocy wewnątrz boszniackiej „wspólnoty wyobrażonej” (Anderson 1998). Nacjonalistyczna interpretacja twórczości Andricia odzwierciedla proces wiktymizacji bośniackich muzułmanów, jaki miał miejsce w latach dziewięćdziesiątych, a także poczucie krzywdy związane z mało zdecydowaną

\footnotetext{
${ }^{18}$ Istnieją też bardziej wyważone analizy krytyczne dzieł Andricia. Część boszniackich badaczy podważa zasadność sławy, jaką pisarz ten cieszy się na Zachodzie, nie domagając się przy tym usunięcia jego pomników z miast zamieszkiwanych w większości przez bośniackich muzułmanów. Popiersia Andricia stoją w obu największych miastach Federacji Bośni i Hercegowiny - Sarajewie i Mostarze.
} 
reakcją Zachodu na oblężenie Sarajewa i czystki etniczne w Bośni i Hercegowinie. Wyraźnie widać to w komentarzu Esada Durakovicia, który dowodził, że Andrić otrzymał Nagrodę Nobla nie tyle za dokonania na polu literatury, ile z racji tego, że prezentował postawę europocentryczną i antymuzułmańską, rzekomo głęboko zakorzenioną w zachodniej kulturze (Lovrenović 2008: 21).

Sposób, w jaki Andrić postrzegał osmańską spuściznę, zgrabnie wkomponowywał się w istniejące mitologie narodowe, które dzielą mieszkańców powojennej Bośni i Hercegowiny. W odróżnieniu od narodowych historyków serbskich i chorwackich, którzy uważają rządy Imperium Osmańskiego na Bałkanach za bolesny cios zagrażający istnieniu ich narodów (i w związku z tym przedstawiają je jako mroczną kartę w historii), intelektualiści boszniaccy widzą ów okres jako etap na drodze ku bośniackiej państwowości. Historycy boszniaccy idealizują rządy osmańskie, w szczególności opisując system milletów jako idealny przykład tolerancji (Baskar 2005: 47), gloryfikując urbanizację (Bougarel 2005: 81) i opiewając osmański przyczynek do cywilizacyjnego postępu. Przekształcają spuściznę osmańską w pozytywnie odbierane dziedzictwo narodowe, czyniąc zeń istotny aspekt boszniackiej tożsamośc ${ }^{19}$.

W ostatnich dziesięcioleciach neoosmanizm stał się znacznie bardziej widocznym elementem dyskursu politycznego w sferze publicznej Bośni i Hercegowiny. Na przykład w marcu 2016 roku media donosiły o dyspucie pomiędzy partiami narodowymi a obywatelskimi w Sanskim Moście. Powodem sporu był fakt, że czołowa partia narodowa Bośni (SDA) poparła i podjęła się organizacji obchodów 101 rocznicy osmańskiego zwycięstwa w bitwie pod Gallipoli, dokładnie w miejscu, gdzie rząd turecki wystawił pomnik żołnierzom poległym podczas oblężenia twierdzy Kamengrad oraz całej kampanii podboju Bośni w roku 1463 (zob. MojUsk). Boszniaccy historycy lubują się w przedstawianiu rozmaitych reinterpretacji osmańskiej inwazji. Autor pracy Historija Bošnjaka (Historia Boszniaków) Mustafa Imamović (1988) twierdzi na przykład, że wtargnięcia wojsk osmańskich na ziemie chorwackie nie należy postrzegać w kategoriach ekspansji terytorialnej, lecz „procesów cywilizacyjnych i kulturowych” (Džaja 2003: 50). Pozytywne aspekty rządów osmańskich omawiane były także podczas konferencji naukowej zorganizowanej przez muzułmańskich uczonych w roku 2003.

Ponieważ nacjonaliści serbscy i chorwaccy odcięli się od osmańskiego dziedzictwa grubą kreską, oceniając je jako bezproduktywny okres ucisku pod obcym jarzmem, środowisko muzułmańskich intelektualistów z Bośni mogło tym łatwiej przedstawić siebie jako spadkobierców wspaniałej cywilizacji oraz naczelnych obrońców spuścizny osmańskiej na współczesnych Bałkanach (Hajdarpašić 2008: 725).

${ }^{19}$ Zachowuję tu rozróżnienie pomiędzy spuścizną a dziedzictwem (Baskar 2005). 
Powstały w tym procesie wyidealizowany, bardzo wybiórczy obraz czasów osmańskich stworzył nowe podstawy pod kolejne bezkrytyczne interpretacje historii Bośni, umacniając tym samym rolę następców Imperium Osmańskiego w powojennej Bośni i Hercegowinie.

\section{Uwagi końcowe}

Andrić nigdy nie uważał się za głosiciela prawd absolutnych. Nuty zwątpienia obecne są nawet w jego pracy doktorskiej. Chociaż stawia śmiałą tezę, że Imperium Osmańskie miało na rozwój Bośni i Hercegowiny jednoznacznie negatywny wpływ i że ciemiężyło swych chrześcijańskich poddanych, wydaje się skonfundowany faktem, iż życie intelektualne kościoła katolickiego kwitło pod rządami Turków. Można również wnioskować, że jako człowiek starszy, Andrić był coraz mniej przekonany, czy jest w stanie przedstawić muzułmanów bez uprzedzeń:

Pisałem o muzułmanach wiele, lecz pilnowałem się, by nie dotykać ich życia osobistego, relacji
z rodziną i podobnych spraw. Po prostu nie czułem się po temu odpowiednią osobą. Moja znajomość
ich życia kończy się na podwórzu; o tym, co dzieje się głębiej, nie wiem już nic (Lovrenović 2008:
30-31).

Ocena Rizvicia, który prezentuje Andricia jako obcokrajowca obserwującego muzułmanów powierzchownie, przez pryzmat chrześcijańskich wyobrażeń, nie jest wiec zupełnie błędna (Rizvić 1995: 243). W pracy doktorskiej Andrić analizował muzułmanów, Imperium Osmańskie i jego spuściznę, a nawet Bośnię i Hercegowinę z pozycji wyżej postawionego, obytego w świecie Europejczyka, a niekiedy także gorliwego zwolennika jugoslawizmu. Nie był jednak całkowicie pewien swojej racji, co widać chociażby w tym, że starannie krył swój doktorat przed publiczną oceną i skutecznie odwlekał jego publikację aż do śmierci. Należy zaznaczyć, że praca doktorska Andricia ukazała się drukiem dopiero w 1982 roku (w wersji dwujęzycznej, po niemiecku i serbsko-chorwacku), ponieważ porzucono oryginalny plan umieszczenia jej w dziełach zebranych tego autora. Decyzję tę thumaczyła nota napisana przez Rodoljuba Čolakovicia, wysoko postawionego członka Związku Komunistów Jugosławii. Wyjaśniał on, że jest to ,pospiesznie napisana praca powierzchownie opisująca kwestie bardzo złożone” (Aleksov 2003: 255).

Andrić zdawał sobie również sprawę, że pominął milczeniem istotne osiągnięcia Imperium Osmańskiego. Zauważył też pozytywne implikacje hybrydyzacji kulturowej. Jak sam pisał:

Turcy (...) postępowali mądrze, bo wiele metod zapożyczali od miejscowej ludności chrześcijańskiej. Czy nie potwierdza tego fakt, iż język narodowy pozostał w codziennym użyciu, tak jak nie zmieniły się sposoby uprawy ziemi i hodowli zwierząt oraz wiele zwyczajów? I chociaż pozostawili po 
sobie wiele, trzeba również przyznać, że i oni ulegali silnym wpływom ziemi bośniackiej, jej ludów i klimatu (Rizvić 1995: 601).

Słowa te interpretować można w politycznym kontekście „braterstwa i jedności”. Wydaje się więc, że w erze nowej Jugosławii orientalizm Andricia przybrał inną szatę. Jego wczesne poglądy wynikały z mieszanki różnych odmian orientalizmu - zarówno tych wypracowanych przez grupy słabe i represjonowane (raya), a później ich znacznie silniejszych potomków, jak i tych uformowanych w kontekście zachodniego dyskursu bałkanistycznego. Ten drugi typ ostatecznie ustąpił przed duchem nowej ery, w której stygmatyzacja islamu i spuścizny osmańskiej zarazem wspótistniała i kolidowała z próbami integracji muzułmańskiej społeczności w procesie budowy państwa jugosłowiańskiego jako równorzędnych partnerów (zob. Lovrenović 2008). W Jugosławii lat sześćdziesiątych XX wieku osmańska spuścizna została przewartościowana, zamieniając się w „cenną tradycję, która dopełniała jugosłowiański socjalizm i jego modernistyczny projekt, zamiast się z nim kłócić" (Hajdarpašić 2008: 729; zob. też: Bougarel 2005).

Rzekoma spójność perspektywy orientalistycznej w pracach Andricia jest zatem jedynie konstruktem współczesnego dyskursu nacjonalistycznego. Wynika z wybiórczego postrzegania jego literackiego dorobku, jakie służyło segregacji narodowościowej w Bośni i Hercegowinie w czasie wojny i po niej. Andrić rzekomo uczył żołnierzy serbskich

\footnotetext{
co się stanie, jeśli „muzułmanie” (czyli potomkowie sturczonych Serbów i Chorwatów) w Bośni i Hercegowinie postanowią oderwać się od Jugosławii w sposób gwałtowny i niekonstytucyjny. W Konsulach ich cesarskich mości Andrić opisuje sturczonych mieszkańców Trawnika (nazywając ich po prostu „Turkami”, takimi jak wszyscy inni) jako bezwzględnych morderców czekających jedynie na okazję, by przelać serbską krew (...) (Tepavac 2001).
}

Dzieła Andricia interpretowane są fragmentarycznie nie tylko w Bośni i Hercegowinie oraz na Bałkanach. Wielu polityków decydujących o losie Bośni także rozumiało jego książki dość selektywnie. Na przykład Klaus Kinkel na wakacyjną lekturę wybrał Most na Drinie, zaś premier Hiszpanii Felipe González, który brał udział w rozmowach pokojowych, twierdził, że z książek Andricia dowiedział się więcej o Bałkanach niż z jakichkolwiek źródeł oficjalnych (zob. Srpsko Kulturno Društvo Prosvjeta). Część badaczy (np. Simić 2000) odwoływało się do książek Andricia w opracowaniach dotyczących genezy niedawnej wojny, w literaturze szukając wyjaśnienia skomplikowanej przeszłości Bośni. Ivan Lovrenović zwraca uwagę, że zwolennicy Radovana Karadžicia rozdawali zachodnim dyplomatom angielskie thumaczenie opowiadania Andricia pod tytułem List z $1920 \mathrm{roku}$ (Lovrenović 2002: 310). To nie przypadek, że angielska wersja językowa doktoratu Andricia opublikowana została w roku 1990 przez Duke University Press, a redaktorzy pracy opisywali ją jako „dokument ważny i ciekawy” (Juričič, Loud 1990: xx). Cztery 
lata później, gdy w Bośni i Hercegowinie wciąż szalała wojna, w Belgradzie ukazało się jej drugie wydanie.

Oczywiście, późniejsze interpretacje dzieł Andricia więcej niż o poglądach pisarza mówią o potrzebach czytelników. Instrumentalizacja jego spuścizny zależna jest od kontekstu. Dawniej szanowany autor i chluba narodu jugosłowiańskiego, w nowych postsocjalistycznych realiach stał się postacią znienawidzoną, a w najlepszym razie niezrozumianą. Jak wspomniano powyżej, stygmatyzacja Andricia w kręgach boszniackich intelektualistów świadczy o zmianie podejścia do imperialnej spuścizny, która przeniosła się w sferę percepcji. Innymi słowy, kiedy mówimy o osmańskim dziedzictwie we współczesnej Bośni i Hercegowinie, natychmiast zauważamy brak alternatywnych wizji czy rywalizujących ze sobą interpretacji politycznych formułowanych w kontekście debat nacjonalistycznych (zob. Hajdarpašić 2008: 723). Pustka ta stanowi niezwykle użyteczne narzędzie segregacji trzech grup narodowych obecnych w Bośni i Hercegowinie, co dobitnie demonstruje chociażby fakt, że całą pracę doktorską Andricia przeczytać można na stronie internetowej stworzonej przez bośniackich Serbów (zob. Slobodna Srpska), chcących wspierać w ten sposób dążenia do ostatecznego oderwania Republiki Serbskiej od Bośni i Hercegowiny. Cel ten kłóci się wyraźnie z konsekwencją, z jaką Andrić agitował ku unifikacji i współpracy między Słowianami Wschodnimi.

\section{Bibliografia}

Aleksov, B. (2003). Poturica gori od Turčina: Srpski istoričari o verskim preobraćenjim. In: H. Kamberović (ed.), Historijski mitovi na Balkanu (p. 223-258). Sarajevo: Institut za istoriju u Sarajevu.

Anderson, B. (1998). Zamišljene skupnosti: O izvoru in širjenju nacionalizma. Ljubljana: Studia humanitatis.

Andrić, I. (1994). Razvoj duhovnog života u Bosni pod uticajem Turske vladavine. Beograd: Prosveta.

Bakić-Hayden, M. (1995). Nesting Orientalisms: the Case of Former Yugoslavia. Slavic Review, 54 (4), 917-931.

Bartulović, A. (2010). "We Have an Old Debt with the Turk, and It Best Be Settled": Ottoman Incursions through the Discursice Optics of Slovenian Historiography and Literature and Their Applicability in the Twenty-first Century. In: B. Jezernik (ed.), Imagining "the Turk" (p. 111-136). Newcastle upon Tyne: Cambridge Scholars.

Baskar, B. (2000). Ambivalent Dealings with an Imperial Past: the Habsburg Legacy and New Nationhood in ex-Yugoslavia. The paper was presented as a lecture at the 
Institut für Ethnologie, Kultur- und Sozialanthropologie, Vienna, November 11th 2003. Pozyskano z: http://planet-austria.at/0xc1aa500d_0x0008062d.pdf.

Baskar, B. (2005). Avstro-ogrska zapuščina. Ali je možna nacionalna dediščina multinacionalnega imperija? In: J. Hudales, N. Visočnik (eds.), Dediščina v rokah znanosti (p. 41-52). Ljubljana: Oddelek za etnologijo in kulturno antropologijo.

Baskar, B. (2010). The First Slovenian Poet in a Mosque: Orientalism in the Travel Writing of a Poet from Imperial Periphery. In: B. Jezernik (ed.), Imagining "The Turk" (p. 97-110). Newcastle upon Tyne: Cambridge Scholars.

Bhabha, H.K. (1996). Culture's In-Between. In: S. Hall, P. du Gay (eds.), Questions of Cultural Identity (p. 53-60). London, Thousand Oaks, Ca., New Delhi: Sage.

Bijelić, D. (2002). Introduction: Blowing up the Bridge. In: D.I. Bijelić, O. Savić (eds.), Balkan as a Metaphor: Between Globalization and Fragmentation (p. 1-22). Cambridge, Massachusetts, London: The MIT Press.

Bougarel, X. (2005). L'héritage ottoman dans les recompositions de l'identité musulmane/ bochniaque. In: S. Gangloff (ed.), La perception de l'héritage ottoman dans les Balkans: The perception of the Ottoman legacy in the Balkans (p. 63-94). Paris: L'Harmattan.

Carmichael, C. (2002). Ethnic Cleansing in the Balkans: Nationalism and the Destruction of Tradition. London, New York: Routledge.

Donia, R. (2013). Bosnia and Herzegovina: The Proximate Colony in the Twilight of Empire. Godišnjak, 42, 197-202.

Džaja, S.M. (2003). Bosanska povijesna stvarnost i njezini mitološki odrazi. In: H. Kamberović (ed.), Historijski mitovi na Balkanu (p. 39-66). Sarajevo: Institut za istoriju u Sarajevu.

Gingrich, A. (1996). Frontier Myths of Orientalism: the Muslim World in Public and Popular Cultures of Central Europe. In: B. Brumen, B. Baskar (eds.), Mediterranean Ethnological Summer School, vol. II, (p. 99-127). Ljubljana: Inštitut za multikulturne raziskave.

Hajdarpašić, E. (2008). Out of the Ruins of the Ottoman Empire: Reflections on the Ottoman Legacy in South-Eastern Europe. Middle Eastern Studies, 44 (5), 715-734.

Herzfeld, M. (1997). Cultural Intimacy: Social Poetics in the Nation-State. New York, London: Routledge.

Huković, M. (2000). Književno dijelo Ive Andrića u svijetlu Madridske deklaracije. In: M. Maglajlić (ed.), Andrić i Bošnjaci: Zbornik radova (p. 109-114). Tuzla: Bošnjačka zajednica kulture Preporod, Općinsko društvo Tuzla. 
Jansen, S. (2002). Svakodnevni orijentalizam: doživljaj "Balkana"/"Evrope" u Beogradu i Zagrebu. Filozofija i društvo: Journal of the Belgrade Institute for Social Research and Philosophy, 18, 33-72.

Jezernik, B. (2004). Wild Europe: The Balkans in the Gaze of Western Travellers. London: Saqi and The Bosnian Institute.

Juričič, Ž., John F.L. (1990). Introduction. In: I. Andrić, The Development of Spiritual Life in Bosnia Under the Influence of Turkish Rule (p. vii-xx). Durham, London: Duke University Pres.

Kamberović, H. (2003). Turci i kmetovi - mit o vlasnicima bosanske zemlje. In: H. Kamberović (ed.), Historijski mitovi na Balkanu (p. 67-84). Sarajevo: Institut za istoriju u Sarajevu.

Karaulac, M. (2003). Rani Andrić. Beograd: Prosveta.

Kazaz, E. (2000). Egzistencijalnost/povijestnost Bosne - Interpretacija u zamci ideologie. Novi izraz, 10 (11). Pozyskano z: http://www.openbook.ba/no10/10_enver_kazaz2. htm.

Kolstø, P. (2003). Procjena uloge historijskih mitova u modernim društvima. In: H. Kamberović (ed.), Historijski mitovi na Balkanu (p. 11-37). Sarajevo: Institut za istoriju u Sarajevu.

Kurtović, Š. (2000). Na Drini ćupija i Travnička hronika od Ive Andrića u svijetlu bratstva i jedinstva. In: M. Maglajlić (ed.), Andrić i Bošnjaci. Zbornik radova. Bibliografija (p. 133-177). Tuzla: Bošnjačka zajednica kulture Preporod, Općinsko društvo Tuzla.

Lindstrom, N. (2003). Between Europe and the Balkans: Mapping Slovenia and Croatia Return to Europe in the 1990s. Dialectical Anthropology, 27, 313-329.

Longinović, T.Z. (1995). East within the West: Bosnian Cultural Identity in the Works of Ivo Andrić. In: W.S. Vucinich (ed.), Ivo Andrić Revised: The Bridge Still Stands (p. 123-138). Berkeley: University of California and Berkeley.

Loud, J.F. (1995). Andrić on Bosnia: The 1924 Dissertation. In: W.S. Vucinich (ed.), Ivo Andrić Revised: The Bridge Still Stands (p. 187-199). Berkeley: University of California and Berkeley.

Lovrenović, I. (2002). The Voices of Sarajevo's Night. Forum Bosnae, 15, 303-312.

Lovrenović, I. (2008). Ivo Andrić: Paradoks o šutnji. Časopis za kulturu, književnost i društvena pitanja, $13(1 / 2), 1-36$.

Maglajlić, M. (ed.) (2000). Andrić i Bošnjaci. Zbornik radova. Bibliografija. Tuzla: Bošnjačka zajednica kulture Preporod, Općinsko društvo Tuzla.

Malcolm, N. (2002). Bosnia: A Short History. London: Pan Books. 
Makdisi, U. (2002). Ottoman Orientalism. American Historical Review, 107 (3), 768-796.

Mastnak, T. (1998). Evropa: med evolucijo in evtanazijo. Ljubljana: Studia Humanitatis.

Rizvić, M. (1995). Bosanski Muslimani u Andrićevu svijetu. Sarajevo: Ljiljan.

Ruthner, C. (2008). Habsburg's Little Orient: A Post/Colonial Reading of Austrian and German Cultural Narratives on Bosnia-Herzegovina, 1878-1918. Kakanien Revisited. Pozyskano z: http://www.kakanien-revisited.at/beitr/fallstudie/CRuthner5. pdf.

Said, E.W. (1991). Orientalizm (przeł. W. Kalinowski). Warszawa: Państwowy Instytut Wydawniczy.

Sang Hun, K. (2011). Andrić as an Object of Hate: Reception of Ivo Andrić's Works in the Post-Yugoslav Context. Slavistična revija, 59 (1), 49-63.

Stojić, M. (1999). Sramnička hronika. BH Dani, 116. Pozyskano z: www.bhdani.com/ arhiva/116/t164a.htm.

Simić, A. (2000). Nationalism as Folk Ideology: The Case of Former Yugoslavia. In: M. Halpern, D.A. Kideckel (eds.), Neighbors at War: Anthropological Perspectives on Yugoslav Ethnicity, Culture and History (p. 103-115). University Park, Pa.: Penn State University Press.

Šarac, D. (2002). Andrić se vraća u Travnik. Slobodna dalmacija. Pozyskano z: http:// arhiv.slobodnadalmacija.hr/inc/print.asp?url=/20021009/temedana01.asp.

Tepavac, M. (2001). Srebrenica i presuda R. Krstića. Pozyskano z: http://www.mail-archive.com/stop-nsp@topica.com/msg01521.html.

Todorova, M. (1996). The Ottoman Legacy in the Balkans. In: C.L. Brown (ed.), "Imperial Legacy": The Ottoman Imprint on the Balkans and the Middle East (p. 45-77). New York: Columbia University Press.

Todorova, M. (1999). Imaginarni Balkan. Beograd: Biblioteka XX vek.

Vervaet, S. (2009). Cultural Politics, Nation Bulding and Literary Imagery: Towards a Post-colonial Reading of the Literature(s) of Bosnia-Herzegovina 1878-1918. Kakanien Revisited. Pozyskano z: https://biblio.ugent.be/publication/1092891/ file/6745133.pdf.

Wachtel, A.B. (1995). Imagining Yugoslavia. The Historical Archeology of Ivo Andrić. In: W.S. Vucinich (ed.), Ivo Andrić Revised: The Bridge Still Stands (p. 82-102). Berkeley: University of California and Berkeley.

Wachtel, A.B. (1998). Making a Nation, Breaking the Nation. Literature and Cultural Politics in Yugoslavia. Stanford: Stanford University Press. 
Wertsch, J.V. (2002). Voices of Collective Remembering. Cambridge: Cambridge University Press.

\section{Źródła internetowe}

Humanitarian Law Center http://www.hlc.org.yu/srpski/Haski_tribunal/Sudjenje_Milosevicu/Transkripti.php?file $=797$. tml

MojUsk http://mojusk.ba/sanski-most-na-mjestu-sukoba-osmanske-i-bosanske-vojskesda-slavi-pobjedu-osmanske-vojske/

Slobodna Srpska http://slobodnasrpska.org/genocid/turci/duhovni_zivot/index.php

Srpsko Kulturno Društvo Prosvjeta http://www.skdprosvjeta.com/news.php?id=286 
